\title{
The Role of the Religious Leader in the Development of Public Policy
}

Joseph Cardinal Bernardin

Follow this and additional works at: https://via.library.depaul.edu/law-review

\section{Recommended Citation}

Joseph C. Bernardin, The Role of the Religious Leader in the Development of Public Policy, 34 DePaul L. Rev. 1 (1984)

Available at: https://via.library.depaul.edu/law-review/vol34/iss1/2

This Article is brought to you for free and open access by the College of Law at Digital Commons@DePaul. It has been accepted for inclusion in DePaul Law Review by an authorized editor of Digital Commons@DePaul. For more information, please contact digitalservices@depaul.edu. 


\section{THE ROLE OF THE RELIGIOUS LEADER IN THE DEVELOPMENT OF PUBLIC POLICY}

\section{INTRODUCTION}

In 1982, DePaul University announced the establishment of the Center for Church/State Studies. Situated in its College of Law, the DePaul Center for Church/State Studies is the only legal research institute in the nation focused sharply on the study of religion and government. The Center is dedicated exclusively to scholarship and therefore does not advocate either partisan political or sectarian religious positions. The Dean of the College of Law has appointed eighteen distinguished legal scholars and practicing attorneys from a wide variety of religious traditions to the Center's executive board.

Early in 1983, well before the presidential campaign began to develop largely around the issue of religion and politics, the Center's executive board decided to look carefully at the issue by sponsoring a symposium on the role of the religious leader in the development of public policy. While there was a great deal of political rhetoric on the pages of the nation's daily newspapers and weekly news magazines, very little reflective and responsible commentary on the proper relationship of religion and politics was available for public consumption. When the American Bar Association heard of the Center's plans to sponsor a symposium on the role of the religious leader in the development of public policy, the American Bar Association offered its annual meeting of over 10,000 lawyers as an appropriate setting for the symposium.

The Center invited Joseph Cardinal Bernardin, Catholic Archbishop of Chicago, to present the major paper, "The Role of the Religious Leader in the Development of Public Policy." Cardinal Bernardin's chairmanship of the American Catholic Bishop's Committee which prepared a landmark document on nuclear war, "The Challenge of Speech: God's Promise, Our Response," provided him with a particularly appropriate perspective from which to address the more theoretical question at issue in our symposium, namely, the proper involvement of religious leaders in the national public policy discussion.

In his major paper, Cardinal Bernardin addresses the moral implications of public policy. He points out two common misconceptions: "that morality is limited to private matters" and "that the development of public policy is a purely secular or political endeavor." He next addresses the role of the Church in the development of public policy, setting forth his arguments for the appropriate place of the Church in the public policy discussion, the appropriate posture that the Church assumes, and the particular perspective the Church uses to guide its participation in the public debate. Lastly, Cardinal Bernardin describes the role of the religious leader in the development of public policy underscoring the critical importance of the religious 
leader's personal credibility, personal limitations, commitment to engage in dialogue on the issues, and personal sense of balance and sensitivity for the broader perspective.

The first formal response to Cardinal Bernardin was given by Dr. Martin E. Marty, Fairfax M. Cone Distinguished Service Professor, University of Chicago Divinity School. Professor Marty is one of the most eminent historians of religion in America. He has published many books, including Righteous Empire, A Cry of Absence, and Pilgrims in Their Own Land, and has received numerous awards, citations, and distinctions. He has taught in the Divinity School at the University of Chicago for the past twenty-one years. Professor Marty's task was to set Cardinal Bernardin's paper in its proper religious historical context.

In his response, Professor Marty reports on what he heard in Cardinal Bernardin's address "that can be placed on the agenda for further discussion and inquiry." The questions Professor Marty raised for careful consideration before the audience of the American Bar Association were whether church/state represents a settled area of national life or not, whether religious leaders and groups have a right to speak up on public issues or not, whether religious leaders and groups are well-counselled to remain silent and uninvolved, whether religious leaders should take the risks in an era when persuasion, not coercion, rules, and whether religious leaders are religious or whether they lead religious groups.

The second formal response was given by the Honorable Arlin M. Adams, Judge of the United States Court of Appeals for the Third Circuit. Judge Adams has distinguished himself as one of the finest scholar-judges in the country. The particular focus of his scholarship has been the religion clauses of the first amendment. He has taught a seminar course on the religion clauses at the University of Pennsylvania Law School for the past fifteen years and is just finishing a two-volume work on church/state legal issues. Judge Adams's task at the symposium was to critique Cardinal Bernardin's paper from the perspective of a constitutional law scholar and an experienced public policy expert.

In his response, Judge Adams takes a somewhat more restricted view of the role of the religious leader in the development of public policy than the one set forth by Cardinal Bernardin. He proceeds from the premise that the "direct involvement of religious leaders in political affairs should be limited and infrequent," a premise that is largely based on the religious leader's primary and inherent concern with transcendence. On the other hand, prudent and wise religious leaders, in Judge Adams's view, are not limited to uttering harmless banalities and pious generalizations.

The full texts of Cardinal Bernardin's address as well as the formal responses of Professor Marty and Judge Adams follow. 


\section{Joseph Cardinal Bernardin*}

First let me express my gratitude to the American Bar Association for its kind invitation to address you this afternoon and to the DePaul University Center for Church/State Studies for organizing this showcase presentation. I would like to commend the American Bar Association for bringing important issues of public concern to the attention of the nation at large. I would also like to pay tribute to the DePaul Center for Church/State Studies because of its impressive initial efforts at sustained legal research into the complex relationship between religion and government in American society.

I have been asked to address a topic to which I have devoted considerable time and reflection during the past year: the role of the religious leader in the development of public policy. I want you to understand clearly at the outset that I do not come before you as a politician or a policy expert; I am a believer and a pastor in the Catholic Church. What I say to you this afternoon is a reflection and extension of the concern of the teaching and practice of the Church throughout the world.

I will address my reflections in three steps: (1) the moral implications of public policy, (2) the Church's role in the development of public policy, and, in the light of this, (3) the role of the religious leader in public policy development.

\section{The Moral Implications of Public Policy}

There are two popular misconceptions that tend to derail discussion about church participation in public policy development. The first is the mistaken notion that morality is limited to personal matters. Religious values are not limited to personal morality and religion. The founding principle of our society is the dignity and worth of every individual. Religious values include recognition of the dignity and worth of all people under God and the responsibilities of a social morality that flow from this belief. Catholic social doctrine is based on two truths about the human person: human life is both sacred and social. Because we esteem human life as sacred, we have a duty to protect and foster it at all stages of development from conception to death and in all circumstances. Because we acknowledge that human life is also social, we must develop the kind of societal environment that protects and fosters its development.

The second popular misconception is that the development of public policy is a purely secular or political endeavor, or merely economic or technological in scope. If this were the case, then the Church and religious leaders would have no specific role in the development of such policy. However, there are important moral and religious dimensions to each of the problems facing the human community, and these dimensions must be taken into consideration in the development of public policy.

Individuals, institutions, and governments frequently make important deci-

* Archbishop of Chicago. 
sions that affect human lives about such issues as distribution of the earth's resources, scientific research, and technological application. Increasingly, voices echoing the concepts of philosophers and the concerns of ordinary people say that the distinctive mark of human genius is to order every aspect of contemporary life in light of a moral vision. A moral vision seeks to direct the resources of politics, economics, science and technology to the welfare of the human person and the human community.

Let me illustrate this with an example. Perhaps the most significant factor that we have to face in our scientific and technological age is that, for the first time in human history, we have the power to destroy ourselves and our world. Forty years ago the German theologian Romano Guardini wrote that the predominant moral issue of the twentieth century would be whether we could develop the moral capacity to control the power we have created. That moral issue still confronts us today with increasing urgency. A directing moral vision is needed to bring the technology of the arms race to its appropriate subordinate role. Only people, however, possess moral vision. Our hope for the future is rooted in people who can express such a vision and in those who are willing to implement it.

For example, the subject of moral purpose and American foreign policy has been a persistent topic in American history. The content of the debate has varied, from the idealism of Wilson to the realism of Morganthau, but the desire to provide moral direction for American policy has been a continuing theme of our national political life. There have always been critics of the theme. In the 1960's Dean Acheson remarked that there were two kinds of problems in foreign policy: real problems and moral problems. However, Mr. Acheson took the subject seriously himself, and, if anything, the salience of moral argument in the policy debate has increased in recent years.

The 1970's were marked by the resurgence of interest in human rights issues, and the 1980's find much of the country involved in a spirited and serious discussion of morality and nuclear policy.

Both issues-human rights and nuclear policy-illustrate the complexity of a moral debate about the ends and means of foreign policy. Both issues highlight, however, that the exclusion of the moral factor from the policy debate is purchased at a high price not only for our values but also in terms of our interests. Allow me to argue the case briefly for the necessity and the possibility of constructing a coherent linkage of moral principles and policy choices.

The necessity of moral analysis in the policy debate is rooted in the character of the issues we faced in the last two decades of this century. The major issues of the day are not purely technical or tactical in nature; they are fundamental questions in which the moral dimension is a pervasive and persistent factor. We live in a world which is interdependent in character and nuclear in context. Interdependence means we are locked together in a limited world. The factual interdependence of our economies raises key questions of access to resources for the industrial nations, but also justice 
in the economic system for the developing nations. The nuclear context of the age brings sharply into focus the problem of keeping the peace in an interdependent world governed by independent states. To build and preserve peace in our world, the key moral question is how we relate politics, economics, and ethics to shape our material interdependence in the direction of moral interdependence.

The Catholic bishops of the United States in their pastoral letter, "The Challenge of Peace: God's Promise and Our Response," spoke of today's dual challenge: building the peace in an interdependent world and keeping the peace in the nuclear age. Both tasks exemplify the necessity of shaping our factual view of the world in terms of the demands of the moral order. The absence of moral vision can erode both our values and our interests.

The possibility of meeting the moral challenge in our conception of policy is rooted in two resources of our country and our culture. The first is part of the constitutional tradition, itself a bearer of moral values including respect for life and reverence for the law, a commitment to freedom and a desire to relate it to justice. To ignore the moral dimension of public policy is to forsake our constitutional heritage.

The second resource is the religiously pluralist character of the nation. The purpose of the separation of church and state in American society is not to exclude the voice of religion from public debate, but to provide a context of religious freedom where the insights of each religious tradition can be set forth and tested. The very testing of the religious voice opens the public debate to assessment by moral criteria. To ignore the moral dimension of public policy is also to forsake our religious heritage.

Who should participate in public policy discussions? In the complexity of our world today, not everything should be left to governments, even though it is impossible to ignore the crucial role of the policies of governments and other major social and economic institutions. Developing and implementing a moral vision for this nation is a task for philosophers and poets, for scientists and statesmen, for social workers and civil servants, for laborers and lawyers and judges-in short, for all citizens. Our effective involvement in building a just and peaceful world will be measured by our ability to think in terms of a guiding moral vision equal to the challenges of the world as we know it today.

This is clearly the thinking of Pope John Paul II who has said that: "Peace cannot be built by the power of rulers alone. Peace can be firmly constructed only if it corresponds to the resolute determination of all people of good will. Rulers must be supported and enlightened by a public opinion that encourages them or, where necessary, expresses disapproval." (World Day of Peace Message, 1982).

In the perspective of this quotation, public opinion plays both a positive and a restraining role. At times it should provide support for necessary but perhaps unpopular initiatives; at other times public opinion should place limits on the direction of policy.

In our American society, individuals and groups are free to participate 
in any dimension of the public debate. This is one of the hallmarks of American democracy. However, individuals and groups must also earn the right to be heard by the quality and consistency of their arguments.

It is clear that public opinion is not always wise and well-formed politically or ethically. The task of trying to shape a well-formed public opinion, which both provides positive direction and sets moral limits for power, is central to the public role of the Church.

\section{The Role of the Church in the Development of Policy}

Because certain issues in the public policy debate are not simply political or economic or technological, but also moral and religious questions, the Church must be a participant in the process.

The participation of the Catholic bishops in public policy discussion is rooted in our conviction that moral values and principles relate to public policy as well as to personal choices. It is also rooted in a belief that we honor our constitutional tradition of religious freedom precisely by exercising our right to participate in the public life of the nation. Entering the policy debate as Catholic bishops we make use of a long detailed tradition of moral analysis and relationships with the universal Church which provide us with valuable perspectives about the influence of U.S. policy throughout the world. These policies include not only the foreign policy of our government, but also business and trade agreements and technological application.

To clarify the Church's role in the development of public policy, let me clarify three basic issues: the place of the Church in the public arena, the posture the Church assumes, and the perspective we use to guide our participation in the public debate.

Explaining the proper place of the Church in the public arena has most often been in response to charges that we are violating the separation of church and state. My experience of the last three and one-half years is that this precious tenet of our constitutional tradition holds a paradoxical place in the public mind. There seems to be an inverse relationship between the readiness of people to invoke the principle and their capacity to understand it clearly.

The phrase is used most often to tell religious bodies to be quiet. However, my reading of the constitutional principle-and the theology which affirms its truth-is that the separation of church and state is designed to provide religious organizations space to speak! To put it succinctly, the separation of church and state means that religious communities should expect neither favoritism nor discrimination in the exercise of their religious and civic functions. They are free to participate in any dimension of the public debate, but they must earn the right to be heard by the quality of their arguments. The place of the Church is separate from the state but must never be separate from society. In society, churches are voluntary associations, free to address the public agenda of the nation. More specifically, they are voluntary associations with a disciplined capacity to analyze the moral-religious significance 
of public issues. That, at least, is how the Catholic bishops see their place in the public policy debate.

That is why we assume a posture which is designed to keep our role both ecclesial and public. The challenge is how to speak as a church to a public issue; how to speak from a tradition of faith in a language which is open to public acceptance by citizens of several faiths or no faith. Early in the pastoral letter on war and peace, the Catholic bishops defined their posture in this way: "As bishops we believe that the nature of Catholic moral teaching, the principles of Catholic ecclesiology and the demands of our pastoral ministry require that this letter speak both to Catholics in a specific way and to the wider political community regarding public policy. Neither audience and neither mode of address can be neglected when the issue has the cosmic dimensions of the nuclear arms race." (The Challenge of Peace, \#19).

Our understanding of our place and posture shapes our perspective. This perspective includes both the traditional teaching of the Church and the particulars of our present circumstances. In the pastoral letter on war and peace, the bishops had two basic purposes: helping Catholics form their consciences on the issues under discussion and contributing to the public policy debate about the morality of war.

Both dimensions have public relevance. If the Church effectively carries out its teaching role, assisting in the formation of adult Christian conscience on matters of war and peace, this will inevitably have an impact on the public perception of these issues. Questions of the limits and obligations of citizenship will be sharpened. In a corresponding fashion, the engagement by the Church as an institution in the public policy debate opens space in the public argument for explicit consideration of the moral dimensions of policy.

Let me acknowledge that the Catholic bishops in this country have assumed more of a public role in our society than was done in the past. The Church has always been active in the public arena not only because of our constitutional freedom to participate but also because of the imperatives of our social doctrine. Although some might see our more assertive posture in terms of being a "post-immigrant" church, I would make a case for our activism based on the extremity of present-day problems. Let me cite two cases.

First, the pastoral letter on war and peace points to the newness of this moment in human history when we literally have in our hands the power to destroy life from the face of this earth. The pastoral letter provides a framework within which we can make a moral analysis of the critical issues facing us in the nuclear age. Although the pastoral letter recognizes the depth and seriousness of divisions between the United States and the Soviet Union on a range of issues, the American bishops were determined that these divisions not divert attention from a central moral and political truth of our time: if nuclear weapons are used, we all will lose. There will be no victors, only the vanquished; there will be no calculation of costs and benefits because the costs will run beyond our ability to calculate. 
Drawing on the same moral vision which supports our teaching on warfare, the Catholic bishops have chosen to be equally visible in our opposition to abortion. The basic moral principle that the direct killing of the innocent is always wrong is so fundamental that the need to defend it in the multiple cases of abortion, warfare, and care of the handicapped and the terminally ill is, we believe, self-evident. That is why one cannot, with consistency, claim to be truly pro-life if one applies the principle of the sanctity of life to other issues but rejects it in the case of abortion. By the same token, one cannot, with consistency, claim to be truly pro-life if one applies the principle to other issues but holds that the direct killing of innocent noncombatants in warfare is morally justified. To fail to stand for this principle is to make a fundamental error. But the moral principle does not stand alone; it is related to other dimensions of the Church's social teaching.

The opposition to abortion is rooted in the conviction that civil law and social policy must always be subject to ongoing moral analysis. Simply because a civil law is in place does not mean that it should be blindly supported. To encourage reflective, informed assessment of civil law and policy is to keep alive the capacity for moral criticism in society. In addition, our position opposing abortion is rooted in our understanding of the role of the state in society. The state has positive moral responsibilities; it is not simply a neutral umpire; neither is its role limited to restraining evil. The responsibilities of the state include both the protection of innocent life from attack and enhancement of human life at every stage of its development. The fact of 1.5 million abortions a year in the United States erodes the moral character of the state; if the civil law can be neutral when innocent life is under attack, the implications for law and morality in our society are frightening.

These themes drawn from Catholic theology are not restricted in their application to the community of faith. These are truths of the moral and political order which are also fundamental to the Western constitutional heritage. The opposition to abortion, properly stated, is not a sectarian claim but a reflective, rational position which any person of good will may be invited to consider. Examples can be used to illustrate the convergence of our concerns about abortion with other key social questions in American society.

The appeal to a higher moral law to reform and refashion existing civil law was the central idea that Dr. Martin Luther King, Jr. brought to the civil rights movement of the 1960's. The pro-life movement of the 1980's is based on the same appeal. Pro-life today should be seen as an extension of the spirit of the civil rights movement. Similarly, the Baby Doe case has proved to be a meeting ground of principle and practice between civil rights and pro-life advocates. The common ground is as yet not sufficiently explored, but there is significant potential for development in this area.

As I conclude this second part of my presentation which dealt with the Church's role in the development of public policy, I wish to repeat something I said earlier. I am not suggesting that religious groups should expect or 
be given special treatment regarding their involvement in the public sphere. We should earn a hearing in the public debate by the quality of our analysis and the consistency of our argument. I am convinced that the moral dimension of our public life is a topic which people inside and outside religious communities are concerned about. If we can demonstrate how a moral vision enriches the choices and the challenges which confront us as a nation, then consideration will be given to the moral factor in every policy debate.

\section{The Role of the Religious Leader in Public Policy Development}

From what I have already said, it should be clear that the Catholic bishop's role in the development of public policy is an extension of his teaching role in the Church, always within the framework of our Catholic tradition and in union with the Pope and other bishops. Because of differences in ecclesial structure, the role of other religious leaders may take a somewhat different shape.

What I would like to share with you in this third section of my presentation is based on my own experience of the last few years, my experience as a religious leader engaged in discussions relating to public policy. Three of my reflections will focus on problem areas and the last will explain the primary source of my motivation and energies.

One of the problems that religious leaders have to face continually is the question of credibility. Some people ignore what we say simply because they perceive us as operating outside our own area of expertise when we make statements regarding public policy. I am not arguing that we have the definitive answers to complex questions or that we have the same kind of competence as foreign policy experts. We do bring a dimension to the discussion that is proper to our competence, however. We merely ask that people evaluate our arguments on their merits. Members of the American Bar Association know what it means to get a fair hearing of your case.

A second problem that religious leaders face is our personal limitation as we attempt to develop the moral dimension of any issue. I am simply Joseph Bernardin-nothing less, nothing more. I have my own blind spots. I have my own doubts. At times I lack the courage to set forth my convictions clearly and without hesitation. Sometimes I simply do not know what to do. Perhaps you have similar experiences in your professional and personal lives.

A key solution is to engage in frequent dialogue with others-with experts in various fields, with respected colleagues, with trusted advisors. The pastoral letter on peace and war was conceived and brought to full term in a process of dialogue. While this was not the first time the bishops have consulted with others in preparing a pastoral statement, none has involved such an open, broad, inter-disciplinary exchange. The bishops debated the contents of the letter in small groups and in general sessions. We collected expert testimony and suggestions from hundreds of people.

A corollary of this is that our participation in the public policy debate 
does not mean that one person or one church or one scholarly community or one think tank has all the answers. Through our participation in dialogue we can share our competencies and God-given personal resources while compensating for our weaknesses and personal limitations. Our collaboration helps ensure the quality of a moral vision for this nation and makes it both credible and worthy of implementation.

A third problem that religious leaders have to face when they engage in public policy development is the pressure that special interest groups bring to bear on the process. I have great respect for people who commit their talents and energies to specific projects that impact in significant ways on public policy discussions. But as a religious leader, I find that $I$ have to keep within my perspective the whole range of issues that affect the quality of human life. Although I may focus my personal resources from time to time on a particular area, it is part of my responsibility as a bishop to keep all these issues in broader perspective and choose prudently and wisely which ones to address at a particular time. This task continues to stretch me. At the same time it can disappoint those who expect a bishop to agree with them on every idea and strategy or who expect a religious leader to be available full time for a particular project.

Two of my goals during the past year have been (1) developing the case for the development of a consistent ethic of life and (2) bringing together under the umbrella of such an ethic individuals and groups who are focusing their energies on a particular area of moral concern. Whether or not I will be successful with regard to the second goal remains to be seen.

With regard to the consistent ethic of life, I am arguing for linking such moral issues as genetics, abortion, capital punishment, modern warfare and the care of terminally ill. Admittedly, these are all distinct problems, enormously complicated, and deserving individual treatment. No single answer and no simple response will solve them.

The purpose of proposing a consistent ethic of life is to argue that success on any one of the issues threatening life requires a concern for the broader attitude in society about respect for human life. Attitude is the place to root an ethic of life. Change of attitude in turn can lead to change of policies and practices in our society.

These are three problems that religious leaders face in my experience, and I have indicated how I am going about resolving these in my own life and ministry.

\section{Martin E. Marty*}

A generation ago the Protestant member of a Protestant-Catholic-Jewish panel who had just heard the Catholic would be expected to speak up for his own communions in criticism of the Catholic. Today the calling and assignment of participants has changed. In any case, my response would

* Fairfax M. Cone Distinguished Service Professor, University of Chicago Divinity School; Associate Editor of The Christian Century. Mr Martin E. Marty is also an ordained Lutheran minister. At the author's request, the text of his response to Cardinal Bernardin appears in its completely unedited form. 
be brief were I only to affirm or criticize what was said. One "Amen!" would take care of that.**

There are other things one can do by way of response, however, since Cardinal Bernardin in his short address raised more issues than he could resolve. I should like to report on what I heard that can be placed on the agenda for further discussion and inquiry. The themes with which he dealt are fresh and even urgent. We need many angles of vision. Today the conflict, then, is not over, but there are new lines. One kind of Protestant, Catholic, and Jew will line up with others of their kind-over against another partisan who is Protestant, Catholic, or Jewish. On another issue, the alliances, which are fluid and fragile in any case, may draw different people across different lines. We shall use the fluidity and fragility as something to be welcomed, not disdained. Let me respond with five uncertain or linedrawing "whethers. . . ."

\section{On Whether Church-State Represents a Settled Area of National Life or Not}

The Cardinal quickens in us all a sense of the ways in which church and state issues are alive, provoking, promising. The DePaul center will not soon work itself out of a job or have to deal only with history. Each new event or constellation seems to disinter other aspects of the founding fathers' proposals. Each test forces a rethinking of what seemed settled. We may even wonder whether "church" and "state," the European ways of putting things serve us in pluralist republic-an America. Madison spoke of the line of separation between the rights of religion and of civil authority.

Whoever reads the newspapers in this election season knows what readings of court decisions these years past should have suggested: everything seems up for grabs. Alfred North Whitehead has said that a clash of doctrines is an opportunity, not a disaster. Since the clash now in this season is not only one of doctrines but of persons, parties, and causes, we have to wallow in opportunity, sometimes asking or wishing for less of it.

We may not like the form it takes; here, again, one calls in Whitehead: "Great ideas enter into reality with evil associates and disgusting alliances. But the greatness remains,. . . ." In any case, the American experiment in religious freedom with its assurances of rights on both and all sides of lines is providing us with what John Courtney Murray called, against the threat of barbarians and the chance of confusion, a "civil argument" based on a minimum of consensus and, he hoped, one hopes, the kind of disagreement out of which argument and perhaps some agreements can grow.

\section{On Whether Religious Leaders and Groups Have A Right to Speak Up on Public Issues or Not}

Cardinal Bernardin, nationally known for advocating the right to speak up, has done so again in this presentation, with personal engagement and 
eloquence. He knows that the "right" is not the only issue: there is often the question of whether such speaking up is good policy for churches and civil agents, and he knows the need for discretion in a pluralist society. Yet good policy and manners are not at issue. Rights are, when the press and the people often suggest that such speaking up violates rights, intrudes across "the wall of separation."

The current conflicts are forcing a rereading of the founders, an assessment of their intentions so far as these are explicit or deducible. There is no doubt that Madison has credentials that make him eminently worth listening to. He was among the more rigorous restricters of the churches when it came to presumed intrusions across the line he and his colleagues drew. Yet he was in favor of what Paul Weber has called "equal separation" of church and state. That meant just as civil authority could not establish or give privilege to churches or religion, it also had to assure that there be, all things being equal, no disability against individuals or groups who spoke up in public life, simply because they were religious. They had to have the same rights as other agents and agencies.

That right is often threatened, if not by law, then at least in opinion and rhetoric. Some citizens thoughtless or momentarily unthinking ones, it seems to me, try to suggest that such disability should and does exist. Were it to lay claim on American thought and rights, this would mean either that only the non-believing five percent dare be elected to office or dare speak up in public life or that citizens have to park their religion at home or in chapel, far from rostrum or campaign or legislature. The cardinal here often shows how people draw on their deepest resources and centers of value, and that these will usually be religious. To draw on them is not to settle everything or much of anything, but it does assure that whole persons are speaking and acting, within their rights and, in the main, for the good of the republic.

\section{II. On Whether, When an Issue Is Urgent, Religious Leaders and Groups Are Well Counselled To Remain Silent and Uninvolved}

The Cardinal knows as anyone of good sense might that religious people need not and should not speak up on all issues. The Protestant right loses some credibility when it treats the Panama Canal treaty or the prolonged existence of the Department of Education as ultimate concerns. It is possible to cry wolf too often, to wear out welcomes, to lead a public to have no scale with which to measure significances. Yet there are times and seasons and issues which call forth the moral counsel of those formed and informed by religion and responsible for leadership in it. Whenever I hear Cardinal Bernardin choosing his moments and causes I think of an adage: "not to take a stand is to take a stand." On gross, even epochal issues, the churches and Christians of Nazi Germany were counted upon by Hitler and were reckoned in his camp.

In the freedom and complexity of the American republic speaking up rarely means representing a bloc of voters, though interests of a church, like those 
of anything else that Madison called a "faction," have their legitimate place. Instead, the religious leader is constantly involved in the open and critical field of convoking respondents, not merely representing them. Madison made much of the need to affect opinion out of which action grew, not merely to render rigid the boundaries around factions.

\section{On Whether Religious Leaders Should Take}

the Risk In an Era Where Persuasion, Not Coercion Rules

From the third "whether" it is clear that in a republic religious leaders have to convince each other, themselves, and their followers, if there is to be support. Blind following, over the long span, is unlikely, rare, and unproductive. Thus, as one sister put it, those who make abortion illegal must first put energies into reasoning across the blocs to make it unthinkable. There are risks in such ventures: risks of division in the ranks, of misrepresentation and confusion, of stimulating anticlericalism, of causing some to be confused and others to be joyless about the Gospel itself because they repudiate the package in which it seems to be coming.

What the Cardinal knows-which is why he appears in forums such as this-is that when the churches do speak up and act, they do lose some of their shield and protection in society. People who are deferential about the sacredness of the churches' message and symbols give them no quarter in the open fray of politics. Church leaders should not be surprised about this; they are no more generous to each other in controversy. They have to know that politics is not the Gospel; it does not save souls or make sad hearts glad. It is a modest art or science designed to minimize the violence inherent in history and to assure the components of society some measure of power proportionate to their weight and scope in society. Churches which enter politics will counter counterorganized factions, and they have to know it.

What if church leaders and groups disagree with each other, as they manifestly do these years, this year-when the debate is more within religion than between the religious and the secular? I would argue that we are still better off than where there is no risk-taking at all. We are closer to realism and reality, exposing the deeper sources of valuation and action. We can call both sides, all sides, to be accountable on some theological terms or other. We can force them to seek what John Courtney Murray called higher levels of generality, in ethics or metaphysics or theology, so that there can be argument. They will often fail to reach these levels, but even the process has validity.

\section{On Whether Religious Leaders Are Religious or Whether They Lead Religious Groups}

I bring this up because any content analysis of the Archbishop of Chicago's speeches and writings or any time-and-motion study suggests to us who are not of his flock that he conceives his task first to be one of spiritual leadership. That should be taken for granted, but it dare not be, given past per- 
formances on the American scene. The last thing evident to one who would use phenomenological methods and bracket assumptions, in other words, to any intuitive and honest reporter who feels things in his or her bones, the last thing the public perceives this year's clergy-in-politics to be is spiritual. The prayers we have been hearing are fawning, the spirit is often greedy and grabby, the representation is boastful and rude. Such advocacy is of short term and little value. Here one must listen again to Peguy: "Everything begins in mysticism and ends in politics"-and then turn everything back, recycling it through "mysticism," a code name here for the life of prayer.

In our mainline Protestant tradition we learned "back in the sixties" how short term is any effort to live off the spiritual capital in which earlier generations invested. When the church in the public order lives off that capital without reinvesting, it soon runs out. The treasure of the church is the lived life of prayer, response to the word, spirituality, nurture, and each generation and agent must contribute to it. When church-in-politics is seen as bureaucracy and taskforce, as unrepresented and unrepresentative of Word or God's people, it soon is seen as an agent of bad faith and loses power.

For that reason I was cheered to hear the Cardinal at an ABA showcase speaking for the prayerful roots of public action among believers. This can be done in a way that combines a sense of the sacred with a tinge of humor, irony, and perspective on one's self-but it must be done, in the nature of the case and if there is to be power.

In other words, the religious leader has to be religious if there is to be long-term and profound leadership. It would be ill-mannered and theologically not apt for the Cardinal to claim for himself what he calls for, just as it would be less than collegial for those of us who have benefited from his mien and acts not to recognize his distinctive and persistent role.

\section{Honorable Arlin M. Adams*}

It is a great honor for me to speak with you today on the role of the religious leader in the development of social policy. I approach the task with considerable diffidence, for 1 am neither a religious leader, nor a scholar of religion. I have had the privilege, though, of filling a number of positions in public and political life which may bear on my assignment. Of particular relevance to the topic we address today, I believe, is the four years I served as Secretary of Public Welfare for Pennsylvania and the fifteen years I served as a judge on the United States Court of Appeals.

I should like first to utilize the position of the judge as a way of approaching today's topic and then, toward the end of my remarks, make reference to my tenure as welfare secretary .

As a judge, it is my responsibility to hear the many controversies litigants bring to our courts for resolution. The most important of these disputes implicate constitutional questions. Judges grow cautious as they approach

* Judge, United States Court of Appeals for the Third Circuit. 
these issues for, in settling such matters, they must decide what the most fundamental document of our legal system means for a particular social controversy. That kind of decision is inherently different from settling a contract dispute between commercial parties or a boundary contest between disgruntled neighbors.

The rules governing the resolution of constitutional questions are quite strict. Judges may not reach out to resolve these issues; rather, they must be inextricably emobodied in the dispute the litigants have brought to court.' And if there is some other way to decide the matter-statutory construction or legal custom, for instance-judges must use that other way to avoid dealing with the constitutional question. ${ }^{2}$

A host of stringent rules also limits the parties who may properly raise constitutional matters ${ }^{3}$ and the occasions on which these matters may be adjudicated. ${ }^{4}$ Should a litigant satisfy these strict criteria and should the case be ripe for decision, the judge must still approach the constitutional issue in a guarded fashion. Our jurisdiction - the authority which legitimizes the judge's decision in a case-is extremely confined when it comes to making a constitutional pronouncement. By deep-rooted tradition, judges must tailor their constitutional conclusions as closely as possible to the facts of the controversy. If a legal precedent fits those facts, it must normally be used. Broad constructions of the Constitution's language must be avoided if narrower readings will suffice. ${ }^{5}$

I have devoted this time to describing the position of the constitutional jurist because I believe that, in many respects, it is the inverse or the mirror image of the role of the religious leader in the developement of social policy. Judges must speak to the particular facts of the actual controversy before them, while religious leaders, in my view, should avoid, except in unusual circumstances, putting the weight of their moral authority behind particular solutions to social problems. Judges should be reticent to declare fundamental

1. See Flast v. Cohen, 392 U.S. 83, 94 (1968); Poe v. Ullman, 367 U.S. 497, 509 (1961) (Brennan, J., concurring) (both cases stating that federal courts are barred from deciding "abstract, hypothetical, or contingent questions"); U.S. ConST. art. III, § 2 (case or controversy requirement); see also Princeton Univ. v. Schmid, 455 U.S. 100 (1982) (federal courts do not decide hypothetical issues nor give advisory opinions).

2. See, e.g., Harris v. McRae, 448 U.S. 297, 306-07 (1980); see also Spector Motor Serv., Inc. v. McLaughlin, 323 U.S. 101, 105 (1944) (federal courts should withhold judgment on questions of constitutionality unless unavoidable).

3. See, e.g., Simon v. Eastern Ky. Welfare Rights Org., 426 U.S. 26 (1976) (standing doctrine). Generally, constitutional rights are personal and may not be asserted vicariously. Broadrick v. Oklahoma, 413 U.S. 601,610 (1973); see also Note, Standing to Assert Constitutional Jus Tertii, 88 HARV. L. REV. 423, 429-30 (1974) (assertion of a third party's constitutional rights or injury will not confer jurisdiction).

4. See Pacific Gas and Elec. Co. v. State Energy Resources Conservation \& Dev. Comm., 461 U.S. 190, 200 (1983) (ripeness); North Carolina v. Rice, 404 U.S. 244, 246 (1971) (mootness doctrine).

5. See generally A. Bickel, The Least Dangerous Branch (1962) (emphasizing the importance of judicial restraint in constitutional adjudication). 
law, whereas the mission of the religious leader is to remind us constantly of the existence and meaning of transcendent principles in our daily lives.

Before I proceed, let me make some disclaimers. Note that I am not addressing my remarks to the religious leader's right to speak out on particular questions troubling the political community. The religious leader has as much right in the constitutional sense to address burning social questions as does any other citizen. But today we are considering the role of the religious leader in developing social policy as a religious leader, and not as a citizen. I am also not suggesting that it is never appropriate for religious leaders to argue for or against particular social programs and policies, although I will maintain, for reasons to be developed later, that their direct involvement in political affairs should be limited and infrequent. Finally, I do not believe that I am restricting religious leaders to uttering harmless banalities and pious generalizations when I admonish against certain types of involvement in political affairs.

I believe that, in approaching particular public policies, the religious leader must be as reluctant as the judge in approaching constitutional questions and that this wariness makes good sense both politically and theologically.

Consider the extraordinary case. What would happen if a leader of one of our principal religions had taken a strong stand on the admission of China to the United Nations, on the proposed treaty relinquishing title to the Panama Canal, or on the host of other policy issues that have captured our political attention in the last decade? By placing his moral and institutional authority behind particular formulations for resolving many political questions, the religious leader would run the risk of transforming the institution he represents into a sect, or in Madisonian political terms, a faction. ${ }^{\circ}$ A fusion of religious authority and partisan politics can lead to a sectarian society, as other religious groups find it necessary to defend conflicting policies they find inherent in their own theological views.

The picture I have just sketched of inordinate religious partisanship also has troubling theological implications. The various religious traditions and institutions that have contributed to the American civilization are based on the notion of transcendence, on the view that the spirit is more than the temporary present. The religious leader must be aware of the threat to this institutional claim to transcendence latent in the use of religious authority to promote particular political policies.

Our religious institutions are so valuable to us politically because they stand above the state, not against it and certainly not with it. The religious leader cannot hold out a transcendent standard by which the state and its policies are to be judged if religious authority becomes narrowly political or too frequently invoked. Indeed, this theological problem might even reemerge as a political danger. As our religious institutions substitute particular political

6. The Federalist No. 10 (J. Madison); see also Ackerman, The Siorrs Lectures: Discovering the Constitution, 93 YalE L.J. 1013, 1022 n.16 (1984) (referring to a religious sect degenerating into a political faction). 
agendas for the universalistic message that is their tradition, the possibility arises that the state or a party might seek to transform a religious institution into its own instrument.

My views on the religious leader and the development of social policy have so far been expressed in the language of politics and theology. Even though I have only some experience in the one, and none in the other, I hope that I have not wearied you with my dull words or my pretentions. I am going to take advantage of your patience because I must unfortunately belabor you with a few philosophical considerations before I can provide a full picture of my view on today's topic.

To discern the proper role of the religious leader in seeking answers to social questions, I believe we must talk for a few moments about a virtue first described by Aristotle ${ }^{7}$ and later made part of our religious tradition by Thomas Aquinas. ${ }^{8}$ That virtue is prudence. The original meaning of this ideal is only partially captured by the typical use of that word today. When we call someone prudent, we are usually praising that person's careful, considered judgment. But to classical thought and Thomistic etiology, prudence meant more than cautious or even thoughtful conduct.

Prudence for the philosopher is a type of wisdom, and there is a different prudence for each of those things about which we may hope to become wise. Thus, the prudent physician is wise about medicine; his judgment is weighty because it rests on a practical knowledge of medical matters acquired only after theoretical study has been fused with years of experience. Prudence, however, is not the exclusive preserve of the formally trained. Some may be wise in a particular endeavor almost as if by nature or by divine blessing. In whatever way it is acquired, prudence in this view of life is necessary before one can truly master a human art. Politics is such an art, I believe, and to be a wise politician, a steward of the commonweal, one must have the virtue of political prudence. A good politician is like a good physician, a good lawyer, or a good artisan. He must understand his craft, however abstractly or concretely, before he can practice with skill.

There is, to be sure, a prudence associated with religious leadership, and that is, I suppose, what we are ultimately called upon to discuss today. We are not interested in just any religious leader. Rather, our focus is on the wise religious leader, the one who is blessed with the prudence necessary to lead a congregation or an institution in this perilous world. I believe that the wise religious leader would recognize that his prudence is not necessarily the sort of wisdom on which a good politician or leader of state will rely. The religious leader will not necessarily have the special wisdom necessary to mold out of political realities a world that is a little more free, or a little more prosperous, or a little more secure.

If we assume that there is no difference between political and religious prudence, we run the same risk involved in our one-time enchantment with

7. Aristotle, Nicomachean Ethics bk. 6 (rev. ed. 1934) (practical wisdom).

8. 1 T. Aquinas, Summa Theologica, Question 1, articles 4-6 (1964). 
science. We were so taken by the wondrous insights of the experimenter that we thought we could transform the political realm, and human nature itself, by the simple application of scientific principles to earthly affairs. The result has been, at least in the nightmares of our story writers, ${ }^{10}$ a technocratic society in which a politicized science eradicates all spontaneity and freedom. Those nightmares are founded on our philosophical and cultural common sense: There is a danger inherent in mistaking a wisdom appropriate in one field as a set of principles that should govern another."

If religious wisdom were transferred directly to the political domain, I fear the same kind of untoward consequences. Our literature may not be replete with the nightmare of theological politics, but the literature of other societies provides a simple moral: It is as much a mistake to abjure political responsibility in the face of religious authority as it is for religious institutions to surrender their independence before the temporal authority of the state.

But surely there must come a point, you might suggest, when religious leaders are duty bound to speak out emphatically and with the full force of their moral power against the evil we inflict on each other. There can be no doubt of that, but how many such occasions are there? I can think of only a few possible candidates in my lifetime, and I doubt that we could all agree on a list of three or four without acrimonious argument. Such debate would be unavailing in my view, for if religious leaders wait to speak out on social affairs until they are confronted by some cataclysmic evil, they have already abdicated their social responsibility. Politics is, at base, a struggle over how society should be structured. Politics is our collective life. Surely our religions have much to teach us about how our everyday life should be ordered.

By now I fear that I have you hopelessly confused. Or perhaps you feel pity for the judge talking above his head about politics, theology, and philosophy. If I think it is unwise for religious leaders, except in unusual circumstances, to adopt particular political positions, have I not condemned these leader to simplistic platitudes and utopian visions? I have two reasons for believing that this criticism misses the mark.

The criticism would be correct only if the message of our religious traditions contains nothing more than virtuous hopes. To say that a wise religious leader would not normally identify his institution with a particular social policy is not to restrict the vitality of the powerful social vision underlying our religions. They call out for a just and holy world. As a judge, I have

9. The possibility of reducing the political process to a mathematical formula or predicting social policy from a sum of private factors is discussed in A. MeikLejohn, Political Freedom The Constitutional Powers of the People 12-13 (1960).

10. See, e.g., A. Burgess, A Clockwork Orange (1962) (deprived of their capacity for moral choice by science, people become a "clockwork orange,"-something mechanical that appears organic).

11. See J. Habermas, Technology and Science as "Ideology," in Toward a Rational Society 81 (1970). 
often felt, and been influenced by, the power of that vision, but only rarely, if ever, have I found that a litigant's arguments completely embody the moral and religious virtues I subscribe to.

Legal and political controversies are never that simple; they invariably involve conflicting interests, each with a certain claim on one's sense of justice and fairness. If they were not complex, they never would have reached the courts: They would have been resolved long before the lawyers were called in. In settling these disputes, we seek to fashion a solution that maximizes the good that is latent in the conflict.

Sometimes judges will see the matter somewhat differently than I; they will favor one interest a little more than another or devise a solution that seems more expedient or less disruptive than the one I proposed. When I disagree with my colleagues about a decision, I would not assert that my view partakes of a transcendent moral legitimacy, and 1 would be quite surprised if my interlocutor were to claim this support for himself. That is not to say that religion does not speak directly to knotty social problems, but rather that it speaks in its own way.

Anyone who has ever had to settle a dispute between people whose actions injure each other knows the value of piety. Without a sense of the message underlying our religious culture, without an appreciation of the fact that political ideologies only imperfectly reflect the good and bad to be found in this life, and without an awareness of personal inadequacy before our ideals, a judge in settling disputes will eventually confuse justice with what in the end remains, legally and morally speaking, a set of personal preferences.

There is another reason for the belief that religious leaders, in avoiding direct political involvement, can do more than utter uplifting generalities. Religious leaders have a duty to see that their congregations and society itself are politically informed. If they offer us simple homilies, they have avoided that responsibility.

Religious leaders, as a matter of moral conviction, should insist that the issues of our day be discussed publicly. They should insist that we not shrink from our moral responsibilities out of political expediency. They should insist that the ethical presuppositions of competing policies be critically examined. To fulfill these duties, religious leaders must provide the means and the occasion by which their congregants can become knowledgeable about pressing social concerns and engage in public debate. Above all, they should not stifle discussion and the development of a just social policy by endorsing a particular view or a particular solution as the theologically correct approach. The latter position, I believe, is politically dangerous and theologically unwise.

I mentioned that I would return to the other public post I have been privileged to occupy-Secretary of Public Welfare. Few things in my life have given me more pause than that office, for I had to shoulder a personal responsibility for the aged, the mentally infirm, the unemployed, the blind, the deaf, and all the many others who sometimes need help to maintain basic human dignity. 
During my tenure as Secretary, I met many religious leaders who embodied the wisdom I have called religious prudence. They had no difficulty in finding a social message in their religious vision. They did not speak in vague platitudes, but in terms of concrete proposals. We discussed, disagreed, cooperated, and sometimes compromised. Not once did we believe that the other's point of view was morally repugnant or religiously defective, for we all knew that we were trying to forge difficult solutions to perhaps intractable problems.

The religious leaders I dealt with in my capacity as Secretary took public stands on some very particularized questions of general concern. They had firm views on how portions of the state's educational budget should be allocated; they lobbied effectively on the use of state funds to help religiously affiliated hospitals and mental institutions. They knew where they stood on a host of social issues, but they did not bring their proposals to me solely as religious leaders. Rather they acted as representatives of agencies pursuing the common good. They acted with both political as well as with religious prudence, and recognized, that the general welfare is a composite of many private needs and social visions. They were able to advance their positions effectively because they knew that their views had to compete with many other equally legitimate views. In our councils, they were able to marshal facts, present arguments, demonstrate fiscal responsibility and the capacity to keep a pledge. They were able to recognize other positions and to compromise. ${ }^{12}$

That kind of compromise was legitimate because these religious leaders were, in effect, political actors representing social programs they knew only inadequately reflected the ideal. Had a matter of religious principle been at stake, compromise would have been much more questionable; perhaps even unacceptable. Had these religious leaders pressed their programs as the good and the just, their interests could not have been served unless the ideas of other well-motivated and politically astute citizens were ignored. Their programs were respected because these leaders could make their case in political terms to public officials seeking to allocate scarce resources most efficiently. An appeal to religious authority to justify a particular program in those circumstances would have been inappropriate and unavailing.

This, then, is my view of the role of religious leaders in the development of public policy. Those leaders should zealously guard the independence of their own institution. They are not the state and should avoid dangerous entanglements with the state. They should eschew elected political office or high appointed posts because in accepting these positions they run the risk of identifying themselves and their institutions with public power.

On the other hand, religious leaders have some responsibility to speak

12. The activity of these religious leaders was completely consonant with the teaching of the noted Catholic philosopher, Jacques Maritain, that "civil legislation should adapt itself to the variety of moral creeds of the diverse spiritual lineages which essentially bear on the common good of the social body. ..." J. Maritain, MAN AND ThE STATE 169 (1951). 
out strongly against serious evils and to do much more. They must inform public debate so that we can avoid catastrophe, but in doing so they must recognize that they will frequently become political actors who must compete under secular rules. When they enter the political sphere, they must recognize that their vision is one of many. Insofar as that vision becomes politically specific, it loses the transcendent authority that may bring it closer to the truth in another sphere.

Religious institutions in our tradition are morally bound to engage the social world. Politics is a major component of that world, but it is not its totality. Our religious leaders must constantly remind us that there is more than mere political imperative and momentary expediency. As they become more particularized in their proposals, they should become more and more wary because they too can succumb to the temptations to which politicians often fall. They can come to identify the good with themselves and a. particular program of social reform with justice itself. In that course lies great danger both to politics and to religion.

Our political culture has inspired great wonder and respect because our Constitution separates religion and the state. Too often we concentrate on one element of that separation; on the fact that the state cannot constitutionally foster particular religions. Commentators as far back as de Toqueville, however, have emphasized the second element: The state may not hinder free expression of legitimate religious belief. ${ }^{13}$

Those who are inspired by religion are bound to be political actors in many respects. Religious leaders must strive to help the members of their flock fulfill their civil duties. At the same time, these leaders must strive to preserve the autonomy of religious institutions.

In this great nation we have usually recognized that religion, the state, and society are not one and the same. If either religion or the state becomes completely identified with society, then our religious and civil culture will suffer.

The real political glory of our nation, I believe, lies in the fact that we refuse to conflate institutions that must stay separate in order to remain vital.

13. A. De Tocqueville, Democracy in America Vol. 1, ch. XVII; Vol. Il, First Book, ch. V; Vol. II, Second Book, ch. IX. 
